\title{
Contributions to Positioning Accounting in Relation to Scientific Research
}

\author{
Vasile Pătruţ, Prof., Dr., "Vasile Alecsandri” University of Bacău
}

\begin{abstract}
The paper approaches some epistemological and methodological aspects of scientific research in accounting, such as: the distinction between accounting research and scientific research in accounting; the products, dynamics and mechanism of scientific creation; scientific research as a fundamental premise of scientific creation; the challenges and conditions of scientific creation; the double standing of accounting, as object and result of the research, in relation to scientific research.
\end{abstract}

\section{Key words}

Accounting research, knowledge, research, scientific research, discovery, invention, innovation.

Sprung from the need to efficiently know and manage the economic values separated in a patrimonial way, accounting asserted itself, within the general process of knowledge, as a double aspect: as practical activity and as scientific theory. Its long history traces an evolution as going "predominantly from practice to theory, where practical experience has been the one anticipating and shaping the theory and method of accounting" ", that is, the science of accounting.

In both of the meanings of the term, accounting has, in our minds, the same object and method and what differs is the level where we stand which is the action level in the first case, respectively the level of the mind, of thought, scientific reflection in the second case. Distinctions can also be made concerning the object and result of each of the two structures. Thus, whereas in the case of accounting as practical activity the object is represented by the movements of concrete values of a clearly defined patrimonial entity and the product is constituted by financial-accounting data regarding that entity, therefore particular statements relative to particular cases, with no scientific relevance, in the case of accounting as scientific theory the object is constituted by the movements of values occurring generally within the patrimony of any entity and the product of the research is constituted by the theoretical statements (which are likely to represent scientific knowledge).

\section{Accounting research versus scientific research in accounting}

Within accounting as a practical activity based on the theoretical and methodological principles elaborated by its scientific theory field, practitioners carry out what is called accounting research. By using the devices of the accounting method, it approaches exhaustively the (economic, legal, administrative or natural) facts which generate movements of values influencing thus the patrimony of a determined entity

${ }^{1}$ Călin, O., Ristea. M. (2002), Bazele contabilităţii, Editura GENICOD, p. 5. 
(organization) and which it seizes, quantifies, eventually recording the respective data; then, these data are processed leading thus to accounting data in the form of some specific indicators and their communication by means of financial-accounting reports with a view to using them.

Scientific research in accounting can be achieved separately from accounting research and it selectively approaches facts concerning the patrimony, in general, of different entities (organizations) and the way in which these facts are treated in the accounting practice with a view to elaborating, by means of specific techniques, general theoretical statements which make up the scientific theory of accounting. The techniques used in this case are related to the methodology of scientific research, unlike the techniques used in accounting research which are related to the accounting method.

The things mentioned so far lead to the conclusion that accounting research and scientific research in accounting are distinguished by object and method, as well as by purpose.

\section{Scientific research - a basic premise of scientific creation}

The motive of the scientific research is generally constituted by knowledge and the need to expand it. As far as knowledge is concerned, it is a "reflex of human curiosity, but also the imperative for survival" . Enlarging upon this idea, the authors of the respective paper - rightfully - claim that "Man would have probably never become an animal aware of its own value had it not been driven from the very beginning towards knowledge. The fact that the initiation was realized at the urging of an inner force is no longer important. Similalrly, there is no particular significance for research in the fact that in the beginning knowledge was achieved towards itself or towards the exterior world of man himself. We may be right in admitting as being more plausible the hypothesis of the beginning of knowing the exterior world, also the one where the most powerful threats might have come from, but also the sources and resources for survival."

Knowledge is the sensory-logical reflection characteristic of a human being. Man's knowledge activity represents, according to the Dictionary of Philosophy ${ }^{3}$, a unity dialectical process of sensory and rational, empirical and theoretical knowledge.

Empirical knowledge is the reflection of the object into the process of unmediated (or mediated by tools and devices) interaction between the subject and object, its specific methods being observation, description etc.. At this level the data which establish the object's external manifestations are collected.

Theoretical knowledge is a process of deepening knowledge through thought, getting to the essence, seizing internal connections, causes and laws which govern the structure of the object. It occurs on the basis of processing the data obtained by empirical knowledge through methods such as analysis and synthesis, induction and deduction etc.

The information acquired in the process of knowledge is structured and fixed in specific reflection forms: sensations, perceptions and representations characteristic of sensory knowledge, notions, judgements, arguments (in logical terms), or concepts, ideas, theses, theories, theoretical systems and other theoretical statements (in epistemological terms) characteristic of rational knowledge.

Concerning human knowledge, its philosophical theory, its gnoseology distinguishes between common knowledge and scientific knowledge. Thus, common knowledge is

2 Zaiţ, D., Spalanzani, A. (2006), Cercetarea în economie şi management; repere epistemologice şi metodologice, Editura Economică, Bucureşti, p. 17.

$3 * * *$ (1978) Dicţionar de filozofie, Editura Politică, Bucureşti. 
identified as the normal, spontaneous, random, generally human manner of reflecting reality that "allows us to use our natural senses in order to identify the explicit

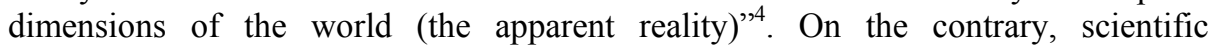
knowledge goes beyond the reality perceivable at the limit of the natural senses. Scientific knowledge is systematic, organized (controlled), based on rigor (that is, principles, rules, procedures, arguments etc.) and is specialized in different domains. Other differences concerning the two types of knowledge concern the type of knowledge results presentation and the recipients. Within the frame of common knowledge, it contributes unconsciously, unwillingly and spontaneously to the increase of the knowledge patrimony with experimental knowledge which is naturally transferred between generations. On the other hand, the results of scientific knowledge materialized into theoretical and practical-applicative generalizations are externalized, that is, formalized and stored in an external memory by implementation into different technical supports and thus making them transferable among generations, regions, distinct structures etc. Usually, the results of scientific knowledge are delivered at a price to those who are to benefit from their exploitation. Depending on how real facts are involved in the research, the authors of the cited paper distinguish among three levels of scientific knowledge: the empirical level, the theoretical level and the application level.

The empirical level seizes the facts, events, emotions, manifestations which represent the reality of the domain under study and identifies the basic and elementary data in the form of empirical data. Since these data are the result of a professional finding (belonging to a specialist in the field) and are subjected to recording in a manner and with tools characteristic of the field, the data or information thus obtained characterize what we call "scientific facts". Therefore, real facts become scientific once they have entered a specialized action of recording and processing where specialized conceptual and methodological tools are used.

So, through the intervention of the specialized conscious (the specialist), which operates with a specialized, formed, acquired, learned etc. language, there occur transformations as the ones below:

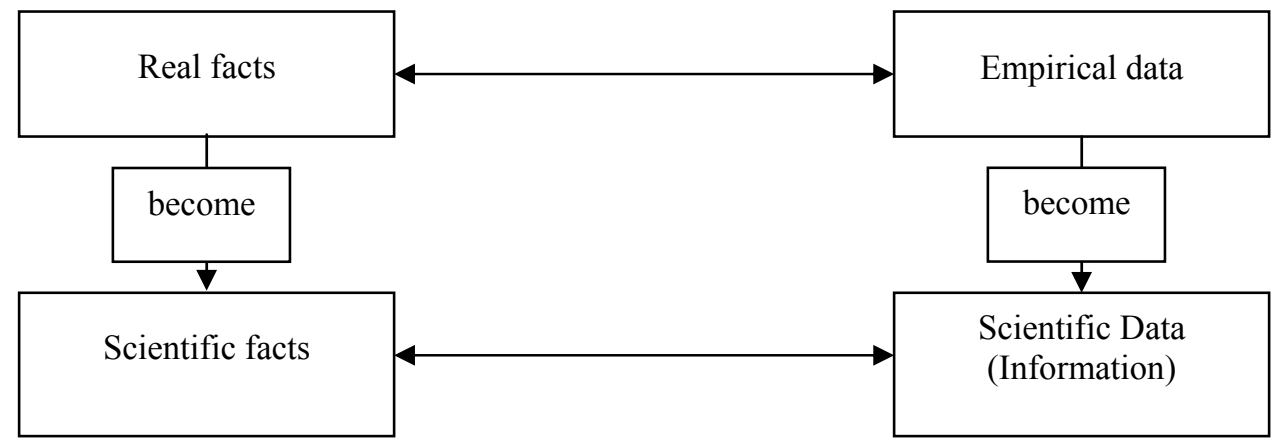

Figure 1. The facts - data relationship

The theoretical level establishes the general and generalizable components of the field, that is, notions (concepts), statements, laws, theses and hypotheses. "In the case of the disciplines in the pragmatic fields of efficient action, where accounting is also

4 Zaiţ, D., Spalanzani, A. (2006), Cercetarea în economie şi management; repere epistemologice şi metodologice, Editura Economică, Bucureşti, p. 17. 
included, at this level (the theoretical one) there are principles and general rules of action for enterprise, sector, activity field and/or time span" ${ }^{\text {" }}$.

The application level, which is located in the area of the occurrence of real facts, yields solutions and recommendations, techniques and procedures etc. through the application of some corresponding theory. This level establishes application rules and norms, principles and methods, as well as the related know-how elements. "It is the efficient action component from scientific knowledge, the one which teaches one how to do what one knows to do. It is about the descriptions and prescriptions needed to effectively carry out the practical activity"6. The scientific research in accounting as an applicative science par excellence aims particularly at its application level.

Table 1. The levels of scientific research

\begin{tabular}{|l|l|l|}
\cline { 2 - 3 } \multicolumn{1}{c|}{} & \multicolumn{1}{c|}{ Location area } & \multicolumn{1}{c|}{$\begin{array}{c}\text { Characteristic elements } \\
\text { operating at this level }\end{array}$} \\
\hline Empirical level & $\begin{array}{l}\text { The interface between } \\
\text { perceptions refined by } \\
\text { previously acquired } \\
\text { specialized knowledge and } \\
\text { the reality of the field as } \\
\text { subject of knowledge in } \\
\text { itself }\end{array}$ & $\begin{array}{l}\text { - real facts } \\
\text { - empirical data } \\
\text { - scientific data } \\
\text { (information) } \\
\text { - scientific facts }\end{array}$ \\
\hline Theoretical level & $\begin{array}{l}\text { General and generalizable } \\
\text { elements of the field (the } \\
\text { interface between the } \\
\text { rational conscious and the } \\
\text { factual reality) }\end{array}$ & $\begin{array}{l}\text { - notions (concepts } \\
\text { - theoretical statements }\end{array}$ \\
\hline Application level & $\begin{array}{l}\text { The area of real facts } \\
\text { occurrence }\end{array}$ & $\begin{array}{l}\text { - hypotheses } \\
\text { - scientific law } \\
\text { - theory }\end{array}$ \\
\hline
\end{tabular}

Scientific creation in the form of discoveries, inventions or, on the edge, innovations, contributes to the expansion of human knowledge which, itself a scientific creation as well, may constitute the purpose of scientific research.

Discovery means achieving new knowledge concerning the objective reality, entering so far unexplored areas as well as understanding certain facts which - although already reported - had not overcome the stage of the gross detail yet ${ }^{7}$. As a discoverer of new truths or as creator of new theories, the human individual or the knowing agent extends the area of human knowledge or suggests the restructuring of the previously known knowledge in the light of new principles. In terms of their predictability, discoveries fall into two categories, expected or unexpected.

Expected discoveries are the ones assiduously searched for, being simultaneously the concern of several researchers. Discoveries of this type belong to development and

5 Zaiţ, D., Spalanzani, A. (2006), Cercetarea în economie şi management; repere epistemologice şi metodologice, Editura Economică, Bucureşti, p. 23.

${ }^{6}$ Zaiţ, D., Spalanzani, A. (2006), Cercetarea în economie şi management; repere epistemologice şi metodologice, Editura Economică, Bucureşti, p. 26.

${ }^{7}$ Dumitraşcu, D. (1974), Trepte spre ştiinţă, Editura Dacia, Cluj, p. 9. 
application researches. In this case, scientific research represents the purpose / objective and the result of what is called scientific research. This research looks into something about which there is some minimal idea, about which one may formulate a hypothesis based on known or suspected facts or events, something which can be logically or emotionally deduced but which needs testing, validation or collecting evidence sufficient for eliminating the risk of counterfeit.

Spontaneous findings, mainly belonging to fundamental researches, open horizons that could not have been suspected before, as a result of chance. In this case, discovery being the role of hazard, researching means looking for something nobody knows anything.

The invention consists in finding a new technical procedure or in building an instrument which, in turn, may support the progress of knowledge and the mastery of nature by man. Through knowledge we explore not only reality, as in the case of discoveries, but also the horizon of possible objects, as in the case of inventions.

Both aspects of creation imply novelty, priority, originality, a way of thinking and of acting which occurs for the first time in the history of science. What distinguishes them is the fact that discovery concerns real facts, already existing but unknown, whereas invention represents constructions of man previously inexistent. The object of discovery is nature or society and that of invention is human activity. These two are indissolubly connected because the invention - of some device, technique or procedure - closely follows or precedes the discovery of a fact, an objective law. Science advances through discovery, technique through invention, and both of them interact. The efficiency of the discovery is measured in ideas while that of the invention in work, action techniques, but both of them are indispensable to progress, to innovation. Innovation understood, of course, as a change applied within a filed, a system where, through the introduction of novelty or through the application of a discovery, an invention or a simple innovation is achieved. Innovation is, according to the DEX, novelty, change, transformation, namely the solving of some technical or work organization problem with a view to improving work (productivity), technical improvement or streamlining of the solutions applied. Therefore, discovery, invention and novelty lead to innovation.

We shall further present several aspects concerning the dynamics and mechanism of scientific creation.

From the scientists' analyses of their own creations, of the way in which they made a discovery, there often resulted "hypertrophies of some factor which participate harmoniously to the act of creation. Thus, the unilateralization of the intuitive moment has led to identifying creation with adventure, with hazard, with chance. Conversely, the exaggeration of the importance of methodical conscious activity systematically carried out according to an organized plan has led to the creation of a false image of scientific creation as a rational and fully controllable process, fundamentally opposed to artistic creation. In fact, says the author cited above, it is a similar process in both circumstances, with different modes of presentation. This is always followed, in the case of science, by a conscious checking and analysis of its products",

There are two premises which allow the correlation of discovery, creation with the subjective side: creativity understood as a complex of skills and as a feature of the spirit, and orienting the creating interest towards creative activity, based on some motivation. The first one represents the potential of creation. The second one fulfils the triggering function for investigation. This is why it marks the outset of elaborating the discovery and supports the process during the subsequent activity.

\footnotetext{
${ }^{8}$ Dumitraşcu, D. (1974), Trepte spre ştiinţă, Editura Dacia, Cluj, p. 13.
} 
In the dynamics of scientific research, A. F. Osborn, cited by D. Dumitraşcu', distinguishes the following stages: 1) orientation: raising an issue; 2) preparation: accumulating specific data; 3 ) analysis: classifying available data; 4) ideation: issuing alternative ideas; 5) incubation: the stop needed to trigger illumination (intuition); 6) synthesis: assembling found data; 7) evaluation: criticizing the ideas obtained.

The solution to a problem may be obtained based on a systematic thinking, as well as through intuition, both of these implying, however, stages of accumulation, incubation and intense thinking.

- Creation needs a prior preparatory period that begins with posing the problem and therefore, with establishing the field of investigation. The starting point cannot be absolutized because we are neither exclusively driven by Bacon's assertion that "science begins with observation", nor by that of K. Popper according to whom "science begins with the problem". The preparation consists in taking possession of the factual material from the explored area and the ceaseless concern towards the problem. "Constantly thinking about the respective object, knowing that one goes to bed with one idea in mind and wakes up still with it" are the words by which I. P. Pavlov revealed his experience. Thus, constant research activity appears to be a first act of creation in science.

- The central moment of creation is the hatching of the original idea. In order for this to occur, it requires a particular tensioning of the intellect, a "forma mentis" favourable to the outbreak. This is achieved due to: 1) numerous favourable influences: associations of ideas, analogies or contrasts suggested by certain words or images, sometimes accidentally perceived; 2) focusing attention or simplifying thought by way of graphic representations, intuitive drawings; 3) systematizing the material in successive stages; 4) noticing contradictions and discrepancies; 5) trying and logicization; 6) discussing the data of the problem; 7) physical states of the cortical activity, those moments of transition between sleep and wake, or of dreaming with no defined objective.

- The last stage of creation is verifying the original idea. This testing is done, first of all, at the level of the argument, applying the first censorship which separates the feasible from the impossible, the value from absurdity. Then confronting the new idea with the observation and experiment material brings about another, more decisive verification. Finally, its practical application and use to the benefit of mankind constitutes the last point of control which certifies and assesses the discovery. The creative cycle ends inducing nevertheless, by coming back to the solid ground of practice, new trajectories in knowledge.

Creative dynamics is not restricted to the three schematic moments, presented above. The transition towards discovery is done, usually, by successive movements, alternative shifts from hypothetical truths to objective truths.

Based on the things we have just analysed, it results that scientific creation is influenced by the following factors:

- imagination (fantasy) - the central prerequisite of originality, with a significant weight in inventing hypotheses;

- intuition (unconscious reason);

- reasoning (rational thinking);

- chance (hazard), as a factor which can act either positively or negatively upon scientific creation;

- systematic research, as a deliberate activity of searching for something, the answer to a question respectively, the solution to a problem.

By synthesizing, the mechanism of scientific creation can be represented as follows:

\footnotetext{
${ }^{9}$ Ibidem, p. 15.
} 
Having the QUESTION / PROBLEM

(identified through the proponent's own experience)

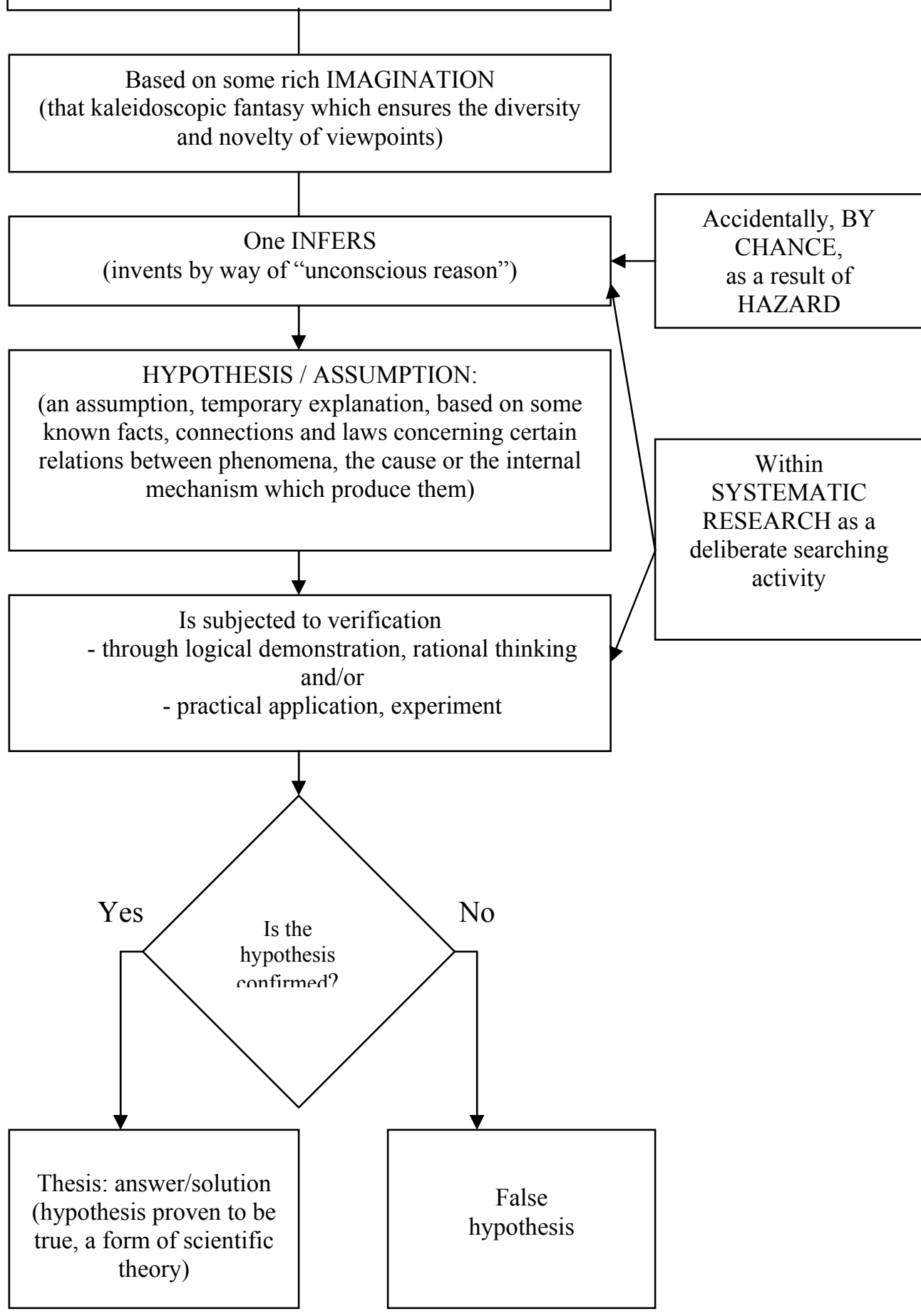

Figure 2. The dynamics of scientific creation 
Taken together, the largest number of discoveries has resulted from a deliberate, systematic activity and not from intuitions or accidental observations. They have developed as a result of a step-by-step activity handed down from generation to generation. Creation cannot be achieved, neither in science nor in art, without a constant concern about a certain problem. If it is true that searching for means finding, then we will have also to agree with the corollary "researching means discovering". Only by being actively involved in a field of the research activity, without counting on hazard, can one have the possibility of being served by it, at a certain moment.

Therefore, scientific creation implies searching for the answer to a question, it requires scientific research. This relation between scientific research and scientific creation results from the very dynamics of the latter. Indeed, this dynamics implies: (1) seizing some question that we would like to have or obtain an answer to, (2) suggesting an answer as a necessary assumption, the answer becoming thus a hypothesis, the hypothesis being the starting point of what we call scientific research, (3) verifying whether the hypothesis is confirmed or false, that is, scientific research. "Scientific research is the systematic, structured and coherent search, based on specific and specialized systems of encoding and on a methodology designed to find what becomes novelty, innovation, invention or discovery. It, the scientific research, aims at finding out something (1) about whose existence nothing is known or (2) about which facts or events connected relationally, empirically or logically are known but for which there is not enough evidence, nor sufficient arguments, demonstrations, logical connections or irrational deductions" $" 10$.

In the case in which something about which nothing is known is being searched for, where it is rather, on the edge, the role of chance, of some hazard which suddenly confronts the factual or relational unknown with the character fated to make the discovery, in this case we are rather dealing with a specious research but which is regarded by many to be the "real" one ${ }^{11}$.

In the theory of knowledge and in epistemology, scientific research is regarded as a logical process of looking for explanations by systematically formulating and testing statements and systems of statements and by building, rebuilding, strengthening or developing the theory on the basis of and within which it is carried out. Scientific research, for empirical studies where the continuous relating to facts, events or relations which are part of the natural reality is compulsory, formulates hypotheses, builds theoretical events and confronts these systems to natural reality, experience, by way of observation and experiment.

Generally, what is characteristic of scientific research is the idea of theorization and implicitly of theoretical generalization, a notional reflection with the help of abstractions, of objective reality. This does not mean that scientific research should not include development research or application research where the first level does not belong to elaborating concepts, theoretical statements and theories, but rules and norms of application, methods, know-how elements.

Any of the sciences uses, in achieving its objective, different methods, their ensemble which is based on the system of the most general laws and principles of the respective science constituting what is called the methodology of that science. With this meaning, the word method is also sometimes used. The same methodology concept is also used with another meaning, that is, to designate the science or theory of methods. "There is a particular methodology of the various sciences which represents the way

10 Preluat şi adaptat din Zaiţ, D., Spalanzani, A. (2006), Cercetarea în economie şi management; repere epistemologice şi metodologice, Editura Economică, Bucureşti, p. 79.

11 Preluat şi adaptat din Zaiţ, D., Spalanzani, A. (2006), Cercetarea în economie şi management; repere epistemologice şi metodologice, Editura Economică, Bucureşti, p. 79. 
of operating with the methods characteristic of each science and with those borrowed from related or interfering disciplines and a general methodology of science, of knowledge, the philosophical part which contains the methods applicable in all domains or, in any case, which meet with a high degree of generality".

\section{The prerequisites and conditions of scientific creation}

Developing further the idea of scientific discovery as the main form of scientific creation, we shall see which are its prerequisites and conditions.

- In order to state a law or to describe a fact scientifically so that it may have the value of a discovery, first of all it needs to reflect reality exactly. A discovery that is not true, is not ... a discovery ${ }^{12}$. This condition eliminates error and forgery from science. In elaborating the discovery, all the rules of research must be obeyed, ensuring objectivity to the content transmitted and fairness to the demonstrative device used. Its value is even greater as it gets closer and closer to the objective truth.

- By definition, discovery consists in: a significant gnoseologic moment, knowing the signification of the new fact. It cannot be confused with the simple description of facts, it is not restricted to this perceptive aspect. Claude Bernard (in Caiet de note. Editura Ştiinţifică, Bucureşti, 1969) pointed out that "discovery is the new idea which arises in connection with a found fact". Only recorded and left unexploited, the original observation cannot have the value of a discovery. "The gross fact does not teach us anything by itself. This does not mean that science denies all of its values but that it files it and keeps it as a premise of future discoveries"13.

- Another prerequisite for discovery is generalizability, according to the specific nature of science which operates with general laws and principles. The concrete fact is nothing than the impulse of scientific knowledge, it does not achieve science itself. Therefore, discovery implies a leap from the mere "to see" to the priceless "to understand"14.

- Recognition of a discovery is conditioned by its diffusibility. A discovery known only by its creator is inexistent to science. Each new contribution gains value only by being increasingly spread around, by being taken over and developed. However, besides the originality of the idea, multiple other factors characteristic of the informational cycle are involved such as the broadcasting sphere of the language in which the discovery is published, the interrelations among countries and scientists etc. Moreover, "it is not enough to make a discovery or briefly describe it, but the new data need to be processed up to a point where others will accept the idea and continue the work" (SELYE, M. - De la vis la descoperire. Editura Medicală, Bucureşti, 1968). To that effect, D. Dumitraşcu mentions that: "Darwin himself was not the first one who noticed the law of the evolution of species, Pasteur himself did not state the microbial theory for the first time. But they are credited to have developed the concepts to which their names have been attached, substantiating them scientifically and bringing them to the field of practical application"15.

- Applicability is another criterion of value for discovery. The correctness of this criterion is undeniable, but not knowing it we cannot overlook the historically conditioned nature that the use of discoveries often implies. Anyway, a discovery should, sooner or later, reflect positively upon man. The moment discoveries are made, the contribution they can bring may remain hidden, as was, for example, the

12 Zaiţ, D., Spalanzani, A. (2006), Cercetarea în economie şi management; repere epistemologice şi metodologice, Editura Economică, Bucureşti, p. 10.

${ }^{13}$ Dumitraşcu, D. (1974), Trepte spre ştiinţă, Editura Dacia, Cluj, p. 12.

${ }^{14}$ Dumitraşcu, D. (1974), Trepte spre ştiinţă, Editura Dacia, Cluj, p. 12.

${ }^{15}$ Dumitraşcu, D. (1974), Trepte spre ştiinţă, Editura Dacia, Cluj, pp. 12-13. 
situation with the discovery of nuclear fusion, at a time when the concept of nuclear power had not yet crystallized.

\section{Accounting - both object and product of scientific research}

In terms of scientific research, accounting is, we believe, both its object and product. As practical activity and everything that this implies, accounting is an object of scientific research and, as scientific theory, accounting is a research product.

As object of scientific research, there may be considered such aspects of accounting practice as the ones covered by the following questions:

- what is there subjected to accounting observation and processing?, respectively, the movements of values which define the object of accounting and the related structures: assets, equity, expenditure, revenue, costs, results etc.;

- where is accounting organized and carried out?, respectively, the accounting entities;

- what is accounting organized and carried out for?, respectively, the aim and objectives of accounting, producing and providing quality data, appropriate to the decision-making process, as well as the degree of using these data;

- for whom?, respectively, the users of accounting data and the satisfaction degree of their informational needs;

- who?, respectively, the processors of accounting information, the responsibilities and the professional staff appropriate to fulfill the accounting function of the organization;

- how?, respectively, the actual methodology and technique for fulfilling effectively the accounting function of the entity, namely: methodological and organizational principles, accounting procedures (documentation, evaluation, accounts system, accounts balance, computation, inventory, balance sheets and all the other synthesis documents and financial reports, economic and financial analysis etc.), accounting norms and standards etc.;

- with what?, respectively, the material resources required by the accounting activity, including characteristic equipment and disposables, proper space etc.;

- how well was the entity's accounting performed?, respectively, the way in which information was certified through financial audit etc.

Like any other science, accounting, too, achieves a dialectical unity by integrating two essential components: theory and scientific method. Theory consists in the accumulated knowledge fund transformed into a rationalized form of concepts and laws, and the method is the way of operating with these in order to keep on expanding knowledge. As a scientific discipline, accounting represents a "system of principles which underlie the way of knowing and managing the economic values in a system, that is: (1) a system of principles and knowledge which explains the connections and relations among the components of the patrimony and, on this base, provides information about how the patrimony should be managed efficiently and, (2) at the same time, methodologically speaking, it elaborates work techniques for performing accounting as an activity, a system of collecting, processing, storing, sending and analysing data concerning the financial position and the performance of the patrimonial entity.

In order to constitute itself as a science, it should:

- have a proper field of research, namely, an area of reality that no other sciences research or that is researched from other viewpoints, that is, its own object of research;

- use scientific methods in investigating its object; 
- reach general truths, a well-rounded theory by way of which it may explain the researched reality (nature, society, thought) in a more profound way, or support practice.

As a form of human knowledge, accounting has had, for a long time, the nature of an empirical knowledge, in that it directly, explicitly and exclusively counted on experience and not on theoretical generalization. With the structuring and establishment of acquired knowledge into notions, categories, judgements, arguments, hypotheses and theories characteristic of rational knowledge, the transition from empirical knowledge to theoretical (systematic) knowledge takes place. Therefore, theoretically approached, accounting is nowadays regarded as a scientific discipline in the field of social sciences, claimed by two families of sciences: economics and management sciences ${ }^{16}$.

Insofar as one accepts the idea that, by vocation and besides the fact that it is a social practice, accounting is also a science in that it defines its object, its method, it states its own scientific theory.

\section{References}

1. Dumitraşcu, D. (1974), Trepte spre ştiinţă, Editura Dacia, Cluj

2. Zaiţ, D., Spalanzani, A. (2006), Cercetarea în economie şi management; repere epistemologice şi metodologice, Editura Economică, Bucureşti

3. Feleagă, N., Malciu, L, Bunea, Şt. (2002), Bazele contabilităţii. O abordare europeană şi internaţională, Editura economică, Bucureşti

4. Ionaşcu, I. (2003), Dinamica doctrinelor contabilităţii contemporane. Studii privind paradigmele şi practicile contabilităţii, Editura Economică, Bucureşti

5. Ionaşcu, I. (1997), Epistemologia contabilităţii, Editura Economică, Bucureşti

6. Călin, O., Ristea. M. (2002), Bazele contabilităţii, Editura GENICOD

7. ** * (1978) Dicţionar de filozofie, Editura Politică, Bucureşti

\footnotetext{
${ }^{16}$ Ionaşcu, I. (2003), Dinamica doctrinelor contabilităţii contemporane. Studii privind paradigmele şi practicile contabilităţii, Editura Economică, Bucureşti, p. 35.
} 